\title{
HUBUNGAN KADAR VITAMIN D DALAM DARAH DENGAN KEJADIAN OBESITAS PADA SISWA SMA PEMBANGUNAN PADANG
}

\author{
Sesmi Nanda Oktavia \\ AKBID PASBAR \\ Email:sesminanda@gmail.com
}

\begin{abstract}
The obesity cases in the world, including Indonesia is increasing. This condition also occurs to senior high school (SMA) Pembangunan students in Padang. There are several factors affecting the obesity occurrence, one them is the level of vitamin D serum. The aims of this study was to identify the relationship between vitamin D levels in the blood and the obesity occurrence.This research used cross sectional study design from March to June 2017. The samples were 82 students from SMA Pembangunan in Padang conducted by using simple random sampling. The level of obesity was determined by measuring body height and weight. The z zscore BMI/age was calculated by using the WHO antro-plus program while the vitamin D level was measured by ELISA method. The statistical analysis used independent sample t-test.The result shows that there is significant difference of the average vitamin $D$ level in the blood of students with obesity compared to normal students $(p=0,025)$. There is also difference in proportion of obesity occurence between the respondents who lack Vitamin D compared to those with adequate level of vitamin $D(p=0,020)$.Based on the research, it is concluded that there is significant relationship between the level of vitamin $D$ in the blood and the occurrence of obesity. Suggestion further research on the effect of vitamin $D$ on obesity needs to be conducted.
\end{abstract}

Keywords: Blood, Obesity, Teenager, Vitamin D

\begin{abstract}
ABSTRAK
Kasus obesitas di dunia, termasuk Indonesia semakin meningkat. Kondisi ini juga terjadi pada siswa SMA Pembangunan di Padang. Ada beberapa faktor yang mempengaruhi terjadinya obesitas, salah satunya adalah kadar vitamin D serum. Tujuan dari penelitian ini adalah untuk mengidentifikasi hubungan antara kadar vitamin D dalam darah dan kejadian obesitas. Penelitian ini menggunakan desain studi cross sectional dari Maret hingga Juni 2017. Sampel penelitian adalah 82 siswa dari SMA Pembangunan di Padang yang dilakukan dengan menggunakan metode acak sederhana. contoh. Tingkat obesitas berdasarkan BMI z score / usia menggunakan antro-plus WHO sedangkan tingkat vitamin $\mathrm{D}$ diukur ELISA. Analisis statistik independent sample t-test, menunjukkan ada perbedaan yang signifikan dari tingkat vitamin $\mathrm{D}$ rata-rata dalam darah siswa obesitas disbanding siswa normal $(\mathrm{p}=0,025)$. Ada perbedaan proporsi kejadian obesitas antara responden yang kekurangan vitamin $\mathrm{D}$ dibandingkan dengan mereka yang memiliki tingkat vitamin D cukup $(\mathrm{p}=0,020)$. Berdasarkan penelitian, disimpulkan ada hubungan signifikan antara tingkat vitamin D dalam darah dan terjadinya obesitas. Saran penelitian lebih lanjut tentang efek vitamin D pada obesitas perlu dilakukan.
\end{abstract}

Kata Kunci: Darah, Obesitas, Remaja, Vitamin D 


\section{PENDAHULUAN}

Obesitas menjadi masalah di seluruh dunia baik di negara maju maupun negara berkembang. World Health Organization (WHO) melaporkan bahwa pada tahun 2008, sekitar 1,4 milyar orang dewasa usia 20 tahun ke atas mengalami overweight dan prevalensi obesitas di dunia yaitu $10 \%$ pada pria dan $14 \%$ pada wanita. Angka ini mengalami peningkatan 2 kali lipat bila dibandingkan dengan tahun 1980 (5\% pada pria dan $8 \%$ pada wanita) (WHO, 2008). Prevalensi kegemukan (obesitas) di negara maju berkisar dari $2.4 \%$ di Korea Selatan hingga 32.2\% di Amerika Serikat, sedangkan di negara berkembang berkisar dari $2.4 \%$ di Indonesia sampai $5.6 \%$ di Saudi Arabia (Low et al, 2009).

Masalah obesitas banyak dialami oleh beberapa golongan masyarakat, antara lain balita, anak usia sekolah, remaja, dewasa, dan lanjut usia (Padmiari and Hadi, 2003). Di Indonesia, berdasarkan data Riset Kesehatan Dasar (Riskesdas) 2007 menunjukkan bahwa $8.8 \%$ remaja berumur $\geq 15$ tahun kelebihan berat dan $10.3 \%$ obesitas. (laki-laki 13,9\% dan perempuan 23,8\%). Berdasarkan Riskesdas $2010 \quad$ prevalensi kegemukan lebih tinggi di perkotaan dibandingkan dengan prevalensi di pedesaan yaitu berturut-turut sebesar $10,4 \%$ dan $8,1 \%$. BerdasarkanRiset Kesehatan Dasar (Riskesdas) 2013 prevalensi gemuk pada remaja usia 13-15 tahun sebesar 10,8 persen, terdiri atas 8,3 persen gemuk dan 2,5 persen sangat gemuk (obesitas), sedangkan prevalensi obesitas pada usia remaja 16-18 tahun adalah 7,3\% yang terdiri dari 5,7\% gemuk dan $1,6 \%$ obesitas.

Dari hasil Riset Kesehatan Dasar (Riskesdas) 2013 prevalensi obesitas pada usia remaja 16-18 tahun di propinsi Sumatera Barat adalah 7,9\%. Sementara itu berdasarkan data Dinas Kesehatan Kota Padang, diketahui bahwa sekolah dengan remaja obesitas terbanyak adalah SMA Pembangunan Padang dengan persentase sebesar 7,7\%.

Obesitas pada remaja penting untuk diperhatikan karena remaja yang mengalami obesitas $80 \%$ berpeluang untuk mengalami obesitas pula pada saat dewasa (Guo and Chumlea, 2000). Selain itu, terjadi peningkatan remaja obesitas yang didiagnosis dengan kondisi penyakit yang biasa dialami orang dewasa, seperti diabetes tipe 2 dan hipertensi. Remaja obesitas sepanjang hidupnya juga berisiko lebih tinggi untuk menderita sejumlah masalah kesehatan yang serius, seperti penyakit jantung, stroke, diabetes, asma, dan beberapa jenis kanker. Stigma obesitas juga membawa konsekuensi psikologis dan sosial pada remaja, termasuk peningkatan risiko depresi karena lebih sering dikucilkan karena berat badan mereka (Puhl and Latner, 2007).

The National Health and Nutrition Examination Survey (NHANES) mengestimasikan 34\% remaja usia 12-19 tahun mengalami obesitas dan lebih dari 32\% diantaranya kemudian diketahui tetap obesitas hingga usia dewasa. Penelitian yang dilakukan oleh Kartini (2013) menyatakan terdapat $14,1 \%$ siswi SMA Theresiana 1 Semarang yang obesitas dan berada di kelas X dan XI. 
Kekurangan vitamin D merupakan faktor risiko independen untuk obesitas dan obesitas abdominal pada wanita (Tamer et al, 2012). Studi terbaru menyebutkan bukti keterkaitan antara obesitas dengan kadar vitamin D yang rendah dalam tubuh. Belum dapat diketahui pasti penyebab defisiensi vitamin D tersebut, apakah karena tidak mendapatkan sinar matahari yang cukup, rendah diet vitamin D atau faktor lain (Gallaqher et al, 2013).

Studi Wortsman et al (2010) menyimpulkan bahwa defisiensi vitamin D akibat obesitas disebabkan oleh penurunan bioavailabilitas vitamin D3 dari kulit dan makanan karena menumpuk di lemak tubuh. Orang yang mengalami obesitas akan kurang mampu untuk mengubah vitamin $\mathrm{D}$ menjadi bentuk aktif. Indeks masa tubuh (IMT) memiliki korelasi berbanding terbalik dengan konsentrasi serum vitamin D3 setelah iradiasi dan dengan konsentrasi puncak serum vitamin D2 setelah asupan vitamin D2 (Wortsman et al, 2000).

Lee et al (2012) menyatakan kekurangan vitamin D telah terkait dengan obesitas, obesitas viseral, hipertrigliseridemia, dan sindrom metabolik pada anak-anak Korea. Ozkan et al (2009) menyatakan bahwa pada anak-anak kadar serum adiponektin telah dilaporkan meningkat pada pasien dengan rakhitis (kekurangan vitamin D), dan penurunan secara signifikan dengan pengobatan vitamin D. Adiponektin disintesis dan disekresikan secara eksklusif oleh jaringan adiposa.

Konsumsi diet sereal yang diperkaya dengan vitamin D dikaitkan dengan penurunan berat badan yang lebih besar dari diet sayuran hijau dan menyebabkan tingkat serum 25OHD3 lebih tinggi (Ortega et al, 2009). Kandungan persentase lemak tubuh secara independen berbanding terbalik untuk tingkat serum 25OHD3 pada wanita yang sehat, terlepas dari diet asupan vitamin $\mathrm{D}$, musim, umur, dan ras (Arunabh et al, 2003). Keterkaitan vitamin D dengan obesitas menjadi daya tarik para peneliti yang memperlihatkan tidak hanya suatu kondisi penimbunan jaringan adiposa, tetapi juga peningkatan kadar leptin. Leptin melalui fibroblast growth faktor-23 (FGF-23), yaitu faktor fosfaturik yang berperan dalam metabolisme vitaminD di ginjal dapat menekan sintesis D 1,25(OH)2, bentuk aktif vitamin D yang dibentuk di ginjal. Selain itu, leptin secara langsung dapat menekan ikatan vitamin D $25(\mathrm{OH})$ yang berada disirkulasi dengan 1 -hydroxylase (CYP27B1) dan 1,25-hydroxyvitamin D-24hydroxylase (CYP24) pada ginjal dan jaringan adiposa. Terdapat pula teori yang menyatakan bahwa dengan peningkatan jaringan adiposa maka vitamin D yang larut lemak akan tersimpan dalam jaringan adiposa tersebut sehingga menyebabkan defisiensi vitamin $\mathrm{D}$.

Calcitriol memiliki peran dalam jaringan adiposa manusia karena merupakan bentuk aktif metabolit vitamin D3, dan reseptor vitamin D (VDR) yang ada dalam adiposit memungkinkan penekanan Tingkat Paratiroid hormon (PTH). Kelebihan PTH dapat menambah berat badan dengan menghambat induksi katekolamin lipolisis (McCarthy et al, 2003). 


\section{METODE PENELITIAN}

Jenis penelitian ini adalah crossectional study karena seluruh variabel diamati dan diukur pada saat bersamaan.

Penelitian

ini

dilaksanakan di SMA Pembangunan Padang pada bulan Maret - Juni 2017. Populasi dalam penelitian ini adalah seluruh siswa SMA Pembangunan kelas I dan II sebanyak 444 orang dengan jumlah sampel sebanyak 82 orang, teknik pengambilan sampel secara simple random sampling yang memenuhi kriteria inklusi. Uji normalitas data dengan Kolmogorof Smirnov, dilanjutkan dengan menganalisis menggunakan uji T-test Independent. dengan kemaknaan $\mathrm{p} \leq 0,05$ $(\alpha=95 \%)$.

\section{HASIL DAN PEMBAHASAN}

Telah dilakukan penelitian observasional dengan disain cross sectional pada siswa SMA kelas $\mathrm{X}$ dan XI. Jumlah sampel dalam penelitian ini sebanyak 82 orang yang berumur 15 sampai 18 tahun, yang sesuai dengan kriteria inklusi dan ekslusi. Terhadap responden dilakukan pemeriksaan kadar vitamin D dalam darah, dan pengukuran berat badan dan tinggi badan, untuk diketahui status gizinya dengan indicator Z Score IMT/U.

Uji normalitas data yang di gunakan adalah uji kolmogorov smirnov, maka didapatkan bahwa kadar vitamin $\mathrm{D}$ dalam darah terdistribusi normal $(\mathrm{p}>0,05)$. Selanjutnya untuk melihat keterkaitan kadar vitamin D dalam darah dengan kejadian obesitas yang dilihat melalui perbedaan rata-rata kadar vitamin $\mathrm{D}$ dalam darah pada siswa obesitas dengan tidak obesitas digunakan uji independent sample $t$ test (parametrik).

Tabel 1. Rata-Rata Umur, Berat Badan, Tinggi Badan dan Kadar Vitamin D Dalam Darah Responden

\begin{tabular}{|c|c|}
\hline Variabel & Mean \pm SD \\
\hline Umur (tahun) & $16 \pm 0,69$ \\
\hline Berat Badan (kg) & $59,79 \pm 16,43$ \\
\hline Tinggi Badan $(\mathrm{cm})$ & $155,65 \pm 6,66$ \\
\hline IMT $\left(\mathrm{kg} / \mathrm{m}^{2}\right)$ & $24,58 \pm 5,96$ \\
\hline $\begin{array}{l}\text { Kadar Vitamin D } \\
\text { dalam darah } \\
(\mathrm{ng} / \mathrm{ml})\end{array}$ & $26,14 \pm 7,84$ \\
\hline $\begin{array}{l}\text { Tabel 1. men } \\
\text { rata-rata umur resp } \\
\text { tahun } \pm 0,69 \text { tahur } \\
\text { badan responden } \\
16,43 \mathrm{~kg} \text {, rata-rat } \\
\text { responden adalah } 1 \\
\text { Responden memilik } \\
\pm 5,96, \text { dan kadar } \\
\text { darah 26,14 } \pm 7,8 \\
\text { batas normal kadar } \\
\text { darah digunakan } \mathrm{m} \\
\text { digunakan (Diagr } \\
\text { Canada) yaitu } 20 \mathrm{sa}\end{array}$ & $\begin{array}{l}\text { unjukkan bahwa } \\
\text { onden adalah } 16 \\
\text { l, rata-rata berat } \\
\text { adalah } 59,79 \pm \\
\text { a tinggi badan } \\
55,65 \pm 6,66 \mathrm{~cm} \text {. } \\
\text { i rata-rata } 24,58 \\
\text { vitamin D dalam } \\
4 \mathrm{ng} / \mathrm{ml} \text { (dalam } \\
\text { vitamin D dalam } \\
\text { enurut kit yang } \\
\text { ostik Biochem } \\
\text { mpai } 50 \mathrm{ng} / \mathrm{ml} \text {. }\end{array}$ \\
\hline
\end{tabular}

Tabel 2. Distribusi Responden Berdasarkan Status Gizi

\begin{tabular}{ccc}
$\begin{array}{c}\text { Status Gizi } \\
\text { (IMT/U) }\end{array}$ & f & $\%$ \\
\hline
\end{tabular}




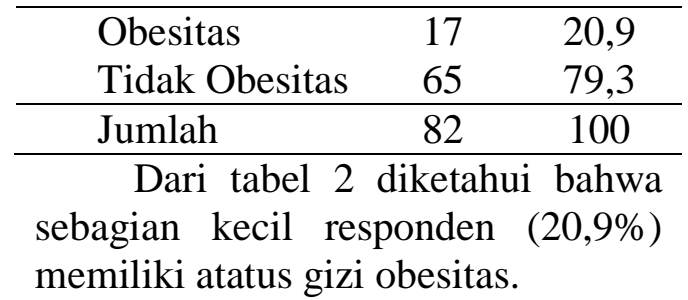

Tabel 3. Distribusi Responden Berdasarkan Kadar Vitamin D dalam darah

\begin{tabular}{ccc}
\hline $\begin{array}{l}\text { Kadar Vitamin } \\
\text { D dalam Darah } \\
\text { (ng/ml) }\end{array}$ & F & $\%$ \\
\hline Cukup & 63 & 76,8 \\
Kurang & 19 & 23,2 \\
\hline Jumlah & 82 & 100 \\
\hline Berdasarkan & tabel 3 & dapat \\
dilihat bahwa $\quad$ sebagian & kecil \\
responden (23,2\%) & memiliki & kadar \\
vitamin D dalam darah yang kurang.
\end{tabular}

Hubungan Kadar Vitamin D dalam Darah dengan Kejadian Obesitas

Distribusi kadar vitamin D dalam darah responden remaja dengan status gizi obesitas dan normal dapat dilihat pada table 4 berikut:

Tabel 4. Perbedaan Rata-Rata Kadar Vitamin D Antara Responden Obesitas dengan Tidak Obesitas

\begin{tabular}{lcc}
\hline \multicolumn{1}{c}{$\begin{array}{c}\text { Status } \\
\text { Gizi }\end{array}$} & $\begin{array}{c}\text { Kadar Vit D } \\
(\mathbf{n g} / \mathbf{m l})\end{array}$ & $\begin{array}{c}\mathbf{p} \\
\text { value }\end{array}$ \\
\hline Obesitas & $22,35 \pm 5,56$ & \\
Tidak & $27,13 \pm 8,08$ & 0,025 \\
Obesitas & &
\end{tabular}

Berdasarkan tabel 5.4.1 dapat dilihat bahwa rata-rata kadar vitamin D responden yang obesitas adalah $22,35 \pm 5,56 \mathrm{ng} / \mathrm{ml}$ sedangkan untuk responden yang tidak obesitas ratarata kadar vitamin D dalam darahnya adalah 27,13 $\pm 8,08 \mathrm{ng} / \mathrm{ml}$. Hasil uji statistik didapatkan nilai $\mathrm{p}=0,025$, yang berarti pada alpha 5\% terlihat ada perbedaan yang signifikan ratarata kadar vitamin D dalam darah antara responden yang obesitas dengan tidak obesitas.

Tabel 5. Distribusi Status Gizi Responden Berdasarkan Kadar Vitamin D dalam Darah

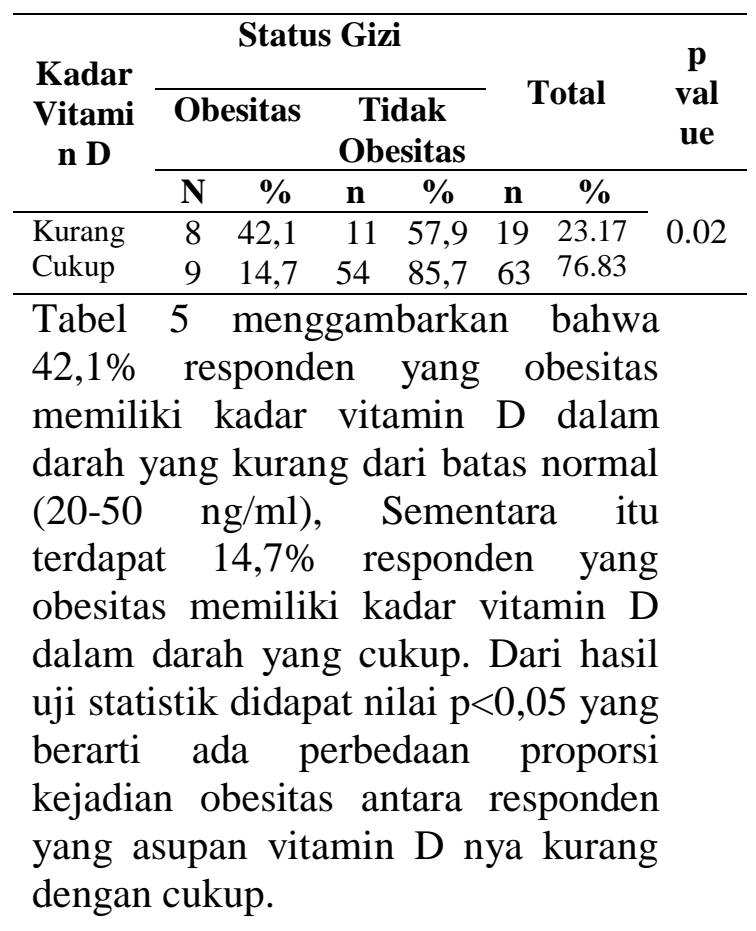

Rata-rata umur, berat badan, tinggi badan, IMT dan kadar vitamin D dalam Darah Responden

Hasil penelitian ini memperlihatkan bahwa rata-rata umur responden adalah 16,3 $\pm 0,69$ tahun. Rata-rata umur ini termasuk dalam batas umur remaja yaitu 12 sampai 18 tahun. Pada penelitian ini ditemukan responden memiliki ratarata berat badan $59,79 \mathrm{~kg} \pm 16,43 \mathrm{~kg}$ dan rata-rata tinggi badan 155,65 \pm $6,66 \mathrm{~cm}$. Sementara itu rata-rata IMT responden adalah $24,58 \pm 5,96$. Hasil rata-rata IMT responden ini berada pada batas akhir rentang normal $(18,5-24,9)$. 
Berdasarkan penelitian ini didapatkan bahwa rata-rata kadar vitamin D dalam darah adalah 26,14 $\pm 7,84 \mathrm{ng} / \mathrm{ml}$. Hasil ini termasuk dalam batas normal kadar vitamin D dalam darah sesuai dengan kit yang digunakan (Diagnostics Biochem Canada) yaitu 20 sampai $50 \mathrm{ng} / \mathrm{ml}$.

\section{Distribusi responden berdasarkan status gizi}

Pada penelitian ditemukan bahwa $(20,9 \%)$ responden memiliki status gizi obesitas. Hasil penelitian ini lebih tinggi dari persentase kejadian obesitas di Provinsi Sumatera Barat menurut Riskesdas 2013 yaitu 7,9 \%, dan juga lebih tinggi dari penelitian yang dilakukan oleh Kartini (2013) yaitu menemukan $14,1 \%$ siswi SMA Theresiana I Semarang dengan obesitas.

Peningkatan prevalensi obesitas disebabkan oleh banyak faktor termasuk genetika, diet, gaya hidup sedentary dan isu-isu yang berkaitan dengan status psikologis, sosial ekonomi, atau pendidikan individu (Van Vliet-Ostaptchouk, 2012). Faktor lingkungan atau interaksi faktor lingkungan dan genetik diduga penyebab paling dominan tingginya prevalensi obesitas ini pada remaja, Ketidakseimbangan antara aktivitas fisik dan tingginya asupan energi dan penambahan gula dan lemak dalam makanan merupakan faktor risiko yang paling dominan (Brown, 2008). Pada penelitian ini tidak dapat digambarkan asupan dan aktivitas fisik responden karena yang diteliti hanya kadar vitamin $\mathrm{D}$ dalam darah.

Obesitas merupakan faktor risiko utama penyakit kardiovaskuler, dan data secara konsisten menunjukkan peningkatan insiden penyakit seiring dengan meningkatnya IMT, akan tetapi obesitas juga merupakan faktor risiko bagi sejumlah kondisi lain yang terkait dengan penyakit kardiovaskuler seperti dislipidemia, diabetes mellitus tipe 2 (dan resistensi insulin) serta hipertensi. Telah diketahui dengan jelas bahwa penumpukan sejumlah besar lemak dalam tubuh akan mengubah fungsi metabolit normal sehingga menghasilkan perubahan yang berpotensi membahayakan (Barasi, 2007).

Obesitas dapat dikendalikan dengan memperbaiki pola makan dan aktivitas fisik, yang melibatkan orangtua dan keluarga. Seluruh anggota keluarga harus terlibat dengan program menjaga berat badan, sementara itu orang tua juga harus memberikan informasi tentang komplikasi yang ditimbulkan oleh obesitas. Jika semua yang terlibat disiplin dan komitmen dengan apa yang dijalankan, maka kejadian obesitas dapat dicegah (Brown, 2008).

\section{Distribusi responden berdasarkan kadar vitamin D dalam darah}

Hasil penelitian menemukan bahwa sebagian kecil responden $(23,2 \%)$ memiliki kadar vitamin D dalam darah yang kurang. Hasil ini lebih rendah dari yang ditemukan oleh Pangestu et al (2005) yaitu $68 \%$. Perbedaan ini disebabkan karena pada penelitian Pangestu et al responden yang diukur kadar vitamin D nya merupakan remaja obesitas, sementara itu pada penelitian ini remaja yang diukur kadar vitamin D 
dalam darahnya merupakan siswa SMA Pembangunan yang diambil secara random sehingga kadar vitamin $\mathrm{D}$ dalam darah tersebut merupakan kadar vitamin $\mathrm{D}$ dalam darah remaja dari berbagai status gizi. Sementara itu berdasarkan tingkat kecukupan kadar vitamin D dalam darah, pada penelitian ini di temukan sebanyak 14,7 \% kadar vitamin $\mathrm{D}$ dalam darah yang cukup pada remaja obesitas, lebih kecil di bandingkan remaja yang tidak obesitas sebanyak $85,7 \%$.

Dalam penelitian ini, meskipun kurangnya kadar vitamin D dalam darah hanya pada sebagian kecil responden, namun hal ini perlu diwaspadai oleh semua pihak, hal ini disebabkan karena akibat yang akan ditimbulkan oleh keadaan tersebut yang akan berdampak pada kehidupan di masa yang akan datang. Jika tubuh kekurangan vitamin D maka hanya $10-15 \%$ diet kalsium dan sekitar $60 \%$ fosfor yang diserap sehingga selain berdampak terhadap penimbunan jaringan adiposa juga dapat mempengaruhi tingkat kepadatan tulang tidak akan tercapai maksimal (Allardt and Viljakainen, 2008; Soliman et al, 2014).

Kurangnya kadar vitamin D pada siswa SMA terkait dengan kekurangan paparan sinar matahari karena budaya dalam berpakaian dan berkerudung atau karena pigmen kulit, dan sedikit waktu yang dihabiskan di luar rumah karena cuaca panas, dan asupan vitamin D yang lebih rendah (Soliman, 2014). Untuk itu upaya pencegahan yang dapat dilakukan adalah memberikan informasi tentang makanan yang mengandung vitamin $\mathrm{D}$ dan manfaat sinar matahari dalam membantu

\begin{abstract}
penyerapan vitamin $\mathrm{D}, \quad$ serta mengaplikasan kegiatan ekstrakurikuler sekolah dengan peningkatan paparan sinar matahari siswa.
\end{abstract}

\section{Hubungan Kadar Vitamin D dalam Darah dengan Kejadian Obesitas pada Siswa SMA Pembangunan Padang.}

Hasil penelitian ini menunjukkan adanya perbedaan ratarata kadar vitamin D dalam darah antara siswa obesitas dengan tidak obesitas. Dengan adanya perbedaan rata-rata tersebut dapat dikatakan ada keterkaitan kadar vitamin D dalam darah dengan kejadian obesitas. Sementara itu berdasarkan distribusi status gizi berdasarkan kadar vitamin D dalam darah, juga terdapat kecenderungan responden obesitas memiliki kadar vitamin $D$ yang kurang (42,1\%) dibandingkan responden obestitas dengan kadar vitamin D yang cukup (14,7\%), dan secara statistik didapatkan hasil ada perbedaan proporsi kejadian obesitas antara responden yang asupan vitamin D nya kurang dengan cukup. Dari hal tersebut dapat dikatakan bahwa ada hubungan yang signifikan antara kadar vitamin D dalam darah dengan kejadian obesitas pada siswa SMA Pembangunan Padang.

Hasil penelitian ini sesuai dengan penelitian yang dilakukan oleh Wortsman et al tahun 2000 yang menyimpulkan defisiensi vitamin D berhubungan dengan kejadian obesitas. Selain itu penelitian yang dilakukan oleh Tzotzas et al, 2010 juga menemukan hal yang senada yaitu terdapat hubungan terbalik antara kadar 25(OH)D3 dengan tingkat keparahan obesitas. 
Kecenderungan ini disebabkan karena fungsi vitamin $\mathrm{D}$ dalam mempengaruhi konsentrasi kalsium terkait dengan obesitas (Heaney et al, 2001). Rendahnya vitamin D mempengaruhi penyerapan kalsium. Kalsium yang rendah akan merangsang ekspresi dan aktivitas fatty acid synthase (FAS), enzim kunci dalam merangsang lipogenesis dan menghambat lipolisis (Shi et al, 2001; Freitas, 2012). Jadi semakin rendah vitamin $\mathrm{D}$ fungsinya dalam membantu penyerapan kalsium juga tidak optimal, sehingga akan dapat memicu terjadinya obesitas (Sergeeve, 2009).

Hasil penelitian ini juga sesuai dengan yang disimpulkan oleh Kamycheva et al tahun 2003 yaitu terdapat hubungan yang berpola negatif antara asupan vitamin D dengan indeks masa tubuh pada responden pria dan wanita, dan penelitian yang dilakukan oleh Arunabh et al (2003) dan menyimpulkan persentase kandungan lemak tubuh berbanding terbalik dengan kadar serum $25(\mathrm{OH}) \mathrm{D} 3$ pada wanita sehat.

Vitamin D dan kejadian obesitas mempunyai hubungan timbal balik, selain kekurangan vitamin $\mathrm{D}$ berhubungan dengan kejadian obesitas, keadaan obesitas pun dapat memicu terjadinya kekurangan vitamin D dalam tubuh. Hal ini disebabkan karena vitamin D larut dalam lemak dan mudah disimpan dalam jaringan adiposa. Muchtadi (2009) mengemukakan bahwa vitamin D diserap tubuh setelah diserap dan disimpan dalam jaringan seperti jaringan otot dan jaringan adiposa, dan kemudian baru dilepaskan secara perlahan ke peredaran darah sesuai dengan kebutuhan tubuh. Menurut Koszowska et al (2014) vitamin D memainkan peran penting dalam fungsi jaringan adiposa. Jika terjadi peningkatan jaringan adiposa maka vitamin D akan menumpuk di jaringan adiposa, sehingga hanya sedikit yang berada di peredaran darah.

Meskipun demikian, hasil penelitian ini tidak sesuai dengan yang didapatkan Scragg et al (2005) yang menyimpulkan kadar serum 25 $(\mathrm{OH})$ D3 tidak terkait dengan indeks massa tubuh. Hal ini disebabkan karena dalam penelitian Scragg et al sampel yang digunakan adalah penduduk Selandia Baru yang didominasi oleh keturunan Eropa yang memiliki IMT lebih tinggi, serta mendistribusikan responden berdasarkan aktivitas fisiknya dan ditemukan kaitan antara kadar vitamin $D$ yang tinggi pada responden yang aktif akibat paparan sinar matahari yang diterima, meskipun secara IMT mereka lebih tinggi. Sementara itu dalam penelitian ini responden tidak dilihat aktivitas fisik dan paparan sinar mataharinya.

Terbuktinya kekurangan vitamin $\mathrm{D}$ berhubungan dengan kejadian obesitas pada penelitian ini memberikan gambaran bahwa antara siswa keluarga dan pihak sekolah perlu kerjasama yang baik keluarga sebagai penyedia makanan hendaknya mampu menyediakan makanan yang mengandung vitamin $\mathrm{D}$, sementara pihak sekolah berperan dalam memberikan informasi tentang dampak dan manfaat dari vitamin D. 


\section{SIMPULAN}

Ditemukan 20,9\% responden memiliki status gizi obesitas. Ratarata kadar vitamin $\mathrm{D}$ dalam darah responden adalah $26,14 \mathrm{ng} / \mathrm{ml}, 23,2$ $\%$ responden defisiensi vitamin $\mathrm{D}$ dalam darah. Terdapat hubungan antara kadar vitamin D dalam darah dengan kejadian obesitas siswa SMA pembangunan Padang.

\section{SARAN}

Disarankan

untuk memberikan penyuluhan yang berkesinambungan tentang vitamin $\mathrm{D}$ dan dampaknya terhadap obesitas.

\section{DAFTAR PUSTAKA}

1. Allardt CJEL and Viljakainen HT. 2008. 25Hydroxyvitamin $D$ and Functional Outcomes in Adolescents. The American Journal of Clinical Nutrition. 88(suppl):534S-6S.

2. Almatsier S. 2003. Prinsip Dasar Ilmu Gizi. Jakarta : PT Gramedia Pustaka Utama.

3. Anderson JJB, Garner SC, Klemmar PJ. 2012. Diet, Nutrients, and Bone Health. Perancis: CRC Press

4. Arunabh $S$, Pollack S, Yeh J, Aloia JF. 2003. Body fat content and 25hydroxyvitamin $D$ levels in healthy women. J Clin Endocrinol Metab. Jan; 88 (1): 157-61.

5. Balitbangkes Depkes R.I. 2007. Laporan Riset Kesehatan Dasar Nasional tahun 2007. Jakarta.
6. Balitbangkes Kementerian Kesehatan. 2010. Riset Kesehatan Dasar (Riskesdas 2010). Jakarta.

7. Balitbangkes Kementerian Kesehatan. 2013. Riset Kesehatan Dasar (Riskesdas 2013). Jakarta.

8. Barasi, M. 2007. Nutrition at a Glance. At a Glance: Ilmu Gizi. Jakarta: Erlangga.

9. Departemen Gizi dan Kesehatan Masyarakat. 2007. Gizi dan Kesehatan Masyarakat. Raja Grafindo Persada. Jakarta.

10. Draznin B, Sussman KE, Eckel RH, Kao M, Yost T, et al. (1988) Possible role of cytosolic free calcium concentrations in mediating insulin resistance of obesity and hyperinsulinemia. J Clin Invest 82: 1848-1852.

11. Erdman JW, Mcdonald IA, Zeisel SH. 2012. Present Knowledge in Nutrition, $10^{\text {th }}$ Edition. International Life Sciences Institutes: WilleyBlack Well

12. Escott S. 2008. Nutrition and Diagnosis- Related Care Sixth Edition. Amerika: Wolter Kluwar

13. Feldman D, Pike JW, Adams JS. 2011. Vitamin D-Volume I- Third Edition. Elsevier

14. Freitas DMO, Martino HSD, Ribeiro SMR, Alfenas RCG. 2012. Calcium Ingestion and Obesity Control. Nutricion Hospitalaria. 27(5):17581771

15. Gallagher JC, Yalamanchili V, Smith LM. 2012. The effect of vitamin $D$ on 
calcium absorption in older women. J Clin Endocrinol Metab. ;97(10):3550-3556.

16. Geissler $\mathrm{C}$ and Powers $\mathrm{H}$. 2005. Human Nutrition 12 th Edition. King's College London, London, UK

17. Heaney RP, Davies M, Barger-lux MJ. 2001. Calcium and Weight: Clinical Studies. Journal of the American College of Nutrition. Vol. 21 no 2

18. Heimburger D and Jamy A. 2006. Handbook of Clinical Nutrition 4 th Edition.University of Alabama at Birmingham, Birmingham, AL.

19. Hensen MC, Castracane VD. 2003. Leptin and Reproduction. New York : Springer Science and Bussiness Media, LLC

20. Kamycheva E，Joakimsen RM, Jorde R (2002) Intakes of calcium and vitamin $\mathrm{D}$ predict body mass index in the population of Northern Norway. J Nutr 132: 102-106.

21. Keputusan Menteri Kesehatan RI. 2010. Standar Antropometri Penilaian Status Gizi Anak. Jakarta: Kemenkes RI.

22. Khor GL, Chee WS, Shariff $\mathrm{ZM}$, Poh KB, Arumagam M, Rahman JA, Theobald HE. 2011. Hight Prevalence of Vitamin D Insufficiency and Its association with BMI for Age Among Primary School Children in Kuala Lumpur Malaysia. BMC Public Health. 11: 95
23. Koszowska AU, Nowak J, Dittfeld A, Puzoń AB, Kulpok A, and Szkodzińska BZ. 2014. Obesity, adipose tissue function and the role of vitamin D. Cent Eur J Immunol.; 39(2): 260-264.

24. Lee SH, Kim SM, Park HS, Choi KM, Cho GJ. 2012. Serum 25-Hydroxyvitamin D Levels, Obesity And The Metabolic Syndrome Among Korean Children. Nutr Metab Cardiovasc Dis. Epub ahead of print.

25. Low S, Chin MC, Deurenberg YM. 2009. Review on Epidemic of Obesity. Singapur : Ann Acad Med.

26. Mann, J \& Truswell, A.S. 2005. Essensial of Human Nutrition. Oxford University Press.P.65

27. McCarty M.F., Thomas C.A. 2003. PTH excess may promote weight gain by impeding catecholamineinduced lipolysis-implications for the impact of calcium, vitamin $D$, and alcohol on body weight. Med. Hypotheses 61: 535-542.

28. Muchtadi D. 2009. Pengantar Ilmu Gizi. Bandung: Alfabeta.

29. Ortega RM, López-Sobaler AM, Aparicio A, Bermejo LM, Rodríguez-Rodríguez E, et al. 2009. Vitamin D status modification by two slightly hypocaloric diets in young overweigh/obese women. Int $\mathrm{J}$ Vitam Nutr Res 79: 71-78.

30. Ozkan B, Doneray H, Keskin H. 2009. The effect of vitamin 
$D$ treatment on serum adiponectin levels in children with vitamin $D$ deficiency rickets. J Clin Res Ped Endo 1: 262-265.

31. Padmiari E, Hadi H. 2001. Konsumsi Fast Food sebagai Faktor Resiko Obesitas pada Anak SD. Medika. 29 : 159165

32. Puhl RM, Latner JD. 2007. Stigma, obesity, and the health of the nation's children. Psychol Bull. 133(4):557-580.

33. Saliba W, Barnett-Griness O, dan Rennert G. 2012. The Relathionship Between Obesity and The Increase in Serum 25(OH)D Levels in Response to Vitamin D Supplementation.

International Osteoporosis Foundation and National Osteoporosis Foundation. DOI 10.1007/s00198- 0122129-0.

34. Sastroasmoro, Sadigdo. 2015. Dasar-dasar metodologi penelitian klinis. Jakarta : Binarupa aksara

35. Scragg R, Holdaway I, Singh $\mathrm{V}$, Metcalf P, Baker J, et al. 2005. Serum 25Hydroxyvitamin D3 Is Related To Physical Activity And Ethnicity But Not Obesity In A Multicultural Workforce. Aust NZ J Med 25: 218-223.

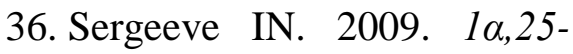
Hydroxyvitamin D3 Induces Ca2+-Mediated Apoptosis In Adipocytes Via Activation Of Calpain And Caspase-12.
Biochem Biophys Res Commun 384: 18-21.

37. Shi H, Norman AW, Okamura WH, Sen A, Zemel MB (2001) 1 $1 \alpha, 25$ hydroxyvitamin D3 modules human adipocyte metabolism via nongenomic action. FASEB J 15: 2751-2753.

38. Soliman AT, De Sanctis V, Elalaily R, Bedair S, and Kassem I. 2014. Vitamin D deficiency in adolescents. Indian J Endocrinol Metab. 18(Suppl 1): S9-S16

39. Tamer G, Mesci B, Tamer I, Kilic D, Arik S. 2012. Is vitamin $D$ deficiency an independent risk factor for obesity and abdominal obesity in women?Endokrynol Pol., 63:196-201 